\title{
TINGKAT PENGETAHUAN, SIKAP DAN PERILAKU WANITA USIA SUBUR TERHADAP DETEKSI DINI KANKER PAYUDARA DENGAN METODE SADARI DI WILAYAH KERJA PUSKESMAS III DENPASAR UTARA TAHUN 2017
}

\author{
A.A Istri Cinya Dewi*, Desak Nyoman Widyanthini, Ni Made Dian Kurniasari \\ Alamat: Program Studi Kesehatan Masyarakat Fakultas Kedokteran Universitas Udayana \\ *Email: gungiscinya@yahoo.com
}

\begin{abstract}
ABSTRAK
Kanker tertinggi yang diderita wanita di Provinsi Bali masih ditempati oleh kanker payudara dan terus meningkat setiap tahunnya. Pada tahun 2014 terdapat 198 kasus kanker payudara dengan CFR sebesar 2\%, sedangkan pada tahun 2015 kejadian kanker payudara meningkat menjadi 380 kasus dengan CFR sebesar $10 \%$. Kasus tertinggi terdapat di Kota Denpasar sebanyak 65\% atau 248 kasus dengan CFR sebesar 15\%. Dari sebelas Puskesmas yang ada di Kota Denpasar, 15\% kasus kanker payudara berada di Puskesmas III Denpasar Utara dan kasus kematian sebanyak 3 orang terdapat di Kelurahan Peguyangan di wilayah Puskesmas tersebut. Penelitian ini bertujuan untuk mengetahui pengetahuan, sikap dan perilaku wanita usia subur terhadap deteksi dini kanker payudara dengan metode SADARI di wilayah kerja Puskesmas III Denpasar Utara. Penelitian ini merupakan penelitian deskriptif kuantitatif dengan rancangan cross-sectional. Populasi sebanyak 7920 WUS, dengan sampel sebanyak 94 responden yang diambil dengan teknik Cluster sampling. Data dikumpulkan dengan wawancara menggunakan kuesioner kemudian dianalisis secara deskriptif. Berdasarkan hasil penelitian 47,87\% responden memiliki pengetahuan cukup, 53,19\% bersikap kurang dan sebagian besar WUS (63,83\%) tidak melakukan SADARI. Adanya kencendrungan tingkat pengetahuan yang paling banyak pada kategori cukup maka dapat menyebabkan sikap yang kurang pula, kemudian dapat berkaitan dengan rendahnya WUS yang melakukan deteksi dini kanker payudara dengan metode SADARI.
\end{abstract}

Kata Kunci : Pengetahuan, Sikap, Perilaku, Deteksi Dini Kanker Payudara Dengan Metode SADARI

\section{ABSTRACT}

Breast cancer is the highest cancer suffered by women in Bali Province and its number continues to increase every year. In 2014, there were 198 breast cancer cases with CFR of 2\%, meanwhile in 2015 the incidence of breast cancer increased to 380 cases with 10\% CFR. The highest cases found in Denpasar City with $65 \%$ or 248 cases and 15\% CFR. A 15\% of them were found in working area of Puskesmas III North Denpasar with 3 fatalities found in Kelurahan Peguyangan. This study aimed to identify knowledge, attitude and behaviour related to early breast cancer detection using breast self-examination among reproductive age women in the working area of Puskesmas III North Denpasar 2017. This was a descriptive quantitative study with cross-sectional design. There were 7,920 population of reproductive age women, then a sample of 94 women were derived using a Cluster Sampling technique. Data were gained through interview using structured questionnaire and analysed descriptively. The results showed that $47,87 \%$ respondents had enough knowledge; $53,19 \%$ had less attitude and $63,83 \%$ had not practiced early breast cancer detection using breast self-examination. Most of the respondents only had enough knowledge, which might lead to their lack of attitude and also caused less practiced of breast self-examination.

Keywords: knowledge, attitude and behaviour, early breast cancer detection using breast self-examination

\section{PENDAHULUAN}

Kanker payudara (Ca mammae) merupakan

tumor ganas terjadi karena terganggunya sistem pertumbuhan sel di dalam jaringan payudara (Nurcahyo, 2010). World Health Organization (WHO) melaporkan kanker payudara merupakan kanker yang paling umum diderita oleh perempuan baik di 
negara maju maupun di negara berkembang. (WHO, 2013). Menurut data International Agency for Research on Cancer (IARC) tahun 2012 diketahui bahwa kanker payudara merupakan penyakit kanker dengan persentase kasus tertinggi, yaitu sebesar $43,3 \%$ dan persentase kematian akibat kanker payudara sebesar 12,9\%. Diperkirakan 519.000 orang wanita meninggal akibat kanker payudara dan sebanyak 69\% kematian tersebut di negara yang sedang berkembang (DepKes RI, 2015). Hasil Riset kesehatan dasar (Riskesdas) 2013 menunjukkan bahwa kanker payudara juga merupakan kanker pembunuh pertama pada wanita di Indonesia. Diperkirakan 40 dari 100.000 wanita di Indonesia mengalami kanker payudara. Berdasarkan data statistik rumah sakit dalam Sistem Informasi Rumah Sakit (SIRS) tahun 2007, kasus rawat inap kanker payudara di Indonesia sebanyak 8.227 kasus (16,85\%), dan meningkat pada tahun 2010 menjadi 12.014 kasus (28,7\%) (Depkes RI, 2009). Kasus kanker payudara di Indonesia menurut Riskesdas 2013 dalam Kemenkes RI (2015) mencapai 0.5\% dengan estimasi jumlah absolut 61.682 kasus sedangkan untuk Provinsi Bali mencapai $0.6 \%$ dengan estimasi jumlah absolut 1.233 kasus di semua usia. Berdasarkan data Surveilans Terpadu Penyakit di Provinsi
Bali kanker tertinggi yang diderita wanita masih ditempati oleh kanker payudara dan terus meningkat setiap tahunnya, pada tahun 2014 kejadian kanker payudara terdapat 198 kasus dengan CFR sebesar 2\%, sedangkan pada tahun 2015 kejadian kanker payudara meningkat menjadi 380 kasus dengan CFR sebesar 10\% dimana kasus tertinggi terdapat di Kota Denpasar yaitu sebanyak 65\% atau 248 kasus dengan CFR sebesar 15\%. Penderita kanker di Kota Denpasar terdiri dari berbagai usia yaitu dimulai dari usia 10 tahun hingga di atas 70 tahun, dan penderita kanker payudara terbanyak berada di usia 20-54 tahun (Dinkes Provinsi Bali, 2015). Dari sebelas Puskesmas yang ada di Kota Denpasar, 15\% kasus kanker payudara berada di Puskesmas III Denpasar Utara dan kasus kematian sebanyak 3 orang berada di Kelurahan Peguyangan di wilayah Puskesmas tersebut (Dinas Kesehatan Kota Denpasar, 2015). Tingginya kematian wanita akibat kanker payudara disebabkan karena sebagian besar wanita yang datang ke Puskesmas sudah berada pada stadium lanjut dan penderita sulit untuk disembuhkan. Kanker payudara sebenarnya penyakit yang dapat dicegah apabila dilakukan deteksi dini. Dilakukannya deteksi dini akan dapat mengetahui apakah 
ada perubahan pada payudara dimana dapat menemukan kanker dalam stadium lebih dini sehingga pengobatannya menjadi lebih baik. Beberapa cara deteksi dini kanker payudara antara lain, pemeriksaan payudara sendiri (SADARI), pemeriksaan payudara klinis (SADANIS) oleh tenaga kesehatan, mammografi, USG, biopsi tanpa pembedahan. Menurut penelitian dari Dyayadi (2009), sebenarnya salah satu cara deteksi dini kanker payudara yang sangat mudah, murah dan tidak memakan waktu yang lama yakni SADARI, dimana deteksi dini kanker payudara dengan metode SADARI ini dapat menekan angka kematian sebesar 25-30\% (Gilbert, 2005). SADARI sangat bermanfaat bagi para wanita usia subur, SADARI dapat mengetahui kelainan payudara sedini mungkin dan lebih cepat mendeteksi kanker payudara stadium dini dibandingan metode deteksi dini kanker lainnya (Dyayadi,2009). Semakin rutin melakukan SADARI maka wanita akan semakin mengetahui kondisi payudaranya sendiri sehingga semakin mudah pula untuk menemukan apabila sesuatu yang tidak normal terjadi, namun pada kenyataannya deteksi dini untuk mencegah kanker payudara masih rendah dilakukan oleh wanita usia subur. Berdasarkan uraian diatas, maka perlu diteliti mengenai

pengetahuan, sikap dan perilaku WUS terhadap deteksi dini kanker payudara dengan metode SADARI di wilayah kerja Puskesmas III Denpasar Utara.

\section{METODE}

Penelitian ini menggunakan metode deskriptif kuantitatif, dengan rancangan Cross Sectional. Populasi target dalam penelitian ini adalah seluruh WUS yang ada di Puskesmas III Denpasar Utara. Sedangkan populasi terjangkau penelitian ini adalah seluruh WUS yang berumur 20-49 tahun di masing-masing desa/kelurahan yang berada di wilayah kerja Puskesmas III Denpasar Utara yang berjumlah 7920. Sampel yang digunakan sebanyak 94 WUS. Dengan kriteria inklusi yaitu, WUS yang berumur 20-49 tahun, tidak dalam keadaan hamil dan menyusui, bertempat tinggal di wilayah kerja Puskesmas III Denpasar Utara dan bersedia menjadi responden. Pemilihan sampel dilakukan menggunakan teknik cluster sampling, dari 49 banjar yang ada di wilayah kerja Puskesmas III Denpasar Utara dipilih 5 banjar secara acak, kemudian dari 5 banjar tersebut dipilih masing-masing 20 sampel wanita usia subur yang berumur 2049 tahun dengan cara simple random sampling. 


\section{HASIL DAN DISKUSI}

\section{Karakteristik Responden}

Karakteristik responden dalam penelitian ini terdiri umur, pendidikan, dan pekerjaan. Dari seluruh responden yang berjumlah 94 WUS didapatkan, kebanyakan responden berumur 20-30 tahun sebanyak

\begin{tabular}{lcc}
\hline $\begin{array}{c}\text { Tingkat } \\
\text { Pengetahuan }\end{array}$ & $\begin{array}{c}\text { Frekuensi } \\
(\mathbf{n = 9 4 )}\end{array}$ & $\begin{array}{c}\text { Persentase } \\
\mathbf{( \% )}\end{array}$ \\
\hline Kurang & 35 & 37,23 \\
Cukup & 45 & 47,87 \\
Baik & 14 & 14,89 \\
\hline Jumlah & $\mathbf{9 4}$ & $\mathbf{1 0 0}$
\end{tabular}

Tabel 1. Tingkat Pengetahuan WUS

Pengetahuan Tentang Deteksi Dini Kanker Payudara Metode SADARI

Sebagian besar responden hanya memiliki tingkat pengetahuan cukup sebanyak $47,87 \%$ responden, hanya sedikit responden yang memiliki pengetahuan baik. Pengetahuan tentang kesehatan yang dimiliki seseorang dapat diperoleh melalui berbagai cara. Adapun cara yang digunakan untuk memperoleh pengetahuan sesuai dengan tabel 1 didapat melalui, pendidikan, media massa, teman maupun dari petugas kesehatan (Arniti, 2009).

Dengan tingkat pengetahuan responden yang sebagian besar hanya berada pada kategori cukup dan kurang menunjukan pemberian informasi tentang deteksi dini kanker payudara metode SADARI sangat
$53,19 \%$ dilihat dari karakteristik pendidikan, responden dominan tamat SMA yaitu sebanyak 47,87\%. Dilihat pula karakteristik pekerjaan responden, untuk karakteristik pekerjaan paling banyak responden bekerja sebagai PNS/Pegawai sebanyak $37,23 \%$ responden seperti dalam tabel 1.

diperlukan. Sehingga WUS dapat menangkap dan memahami informasi yang lebih banyak dan diharapkan dapat mendukung kesiapan WUS untuk mengambil keputusan dalam melakukan deteksi dini kanker payudara metode SADARI.

Dari sepuluh pertanyaan yang diajukan kepada responden, pengetahuan responden masih kurang mengenai waktu yang tepat melakukan SADARI hanya sebanyak 38,30\% responden yang menjawab benar, apabila SADARI tidak dilakukan pada waktu yang tepat maka benjolan atau pembengkakan pada payudara tidak dapat dirasakan saat diraba oleh WUS, karena 5-7 hari setelah menstruasi retensi cairan minimal dan payudara dalam keadaan lembut dan tidak membengkak sehingga jika ada pembengkakan akan lebih mudah ditemukan. 
Tabel 2. Pertanyaan untuk mengetahui tingkat pengetahuan WUS tentang kanker payudara dan SADARI

\begin{tabular}{|c|c|c|}
\hline \multirow[t]{2}{*}{$\begin{array}{l}\text { Pertanyaan } \\
\text { Pengetahuan }\end{array}$} & \multicolumn{2}{|c|}{$\begin{array}{c}\text { Responden yang Menjawab } \\
\text { Benar }\end{array}$} \\
\hline & $\begin{array}{c}\text { Frekuensi } \\
(\mathrm{n}=94)\end{array}$ & $\begin{array}{c}\text { Persentase } \\
(\%)\end{array}$ \\
\hline Pengertian Kanker & 66 & 70,21 \\
\hline \multicolumn{3}{|l|}{ Payudara } \\
\hline Kanker & 83 & 88,30 \\
\hline \multicolumn{3}{|l|}{ Payudara } \\
\hline Faktor Resiko Kanker & 73 & 77,66 \\
\hline \multicolumn{3}{|l|}{ Payudara } \\
\hline Deteksi Dini Kanker & 77 & 81,91 \\
\hline \multicolumn{3}{|l|}{ Payudara } \\
\hline Pengertian SADARI & 66 & 70,21 \\
\hline Manfaat SADARI & 73 & 77,66 \\
\hline Pelaksanaan SADARI & 39 & 41,49 \\
\hline Waktu yang tepat & 36 & 38,30 \\
\hline \multicolumn{3}{|l|}{ melakukan SADARI } \\
\hline Tahapan SADARI & 47 & 50,00 \\
\hline Langkah-langkah & 44 & 46,81 \\
\hline SADARI & & \\
\hline
\end{tabular}

Disusul pada pertanyaan mengenai pelaksanaan SADARI sebanyak 41,49\% responden, apabila pelaksanaan SADARI tidak dilakukan sebelum menderita kanker payudara dikhawatirkan sebagian besar WUS menyadarinya pada saat sudah stadium lanjut maka akan lebih susah untuk disembuhkan, karena pemeriksaan sebelum menderita kanker payudara juga sangat membantu petugas kesehatan menemukan kondisi medis tertentu seperti infeksi atau tumor yang dapat menjadi serius jika tidak diobati. Selanjutnya pertanyaan mengenai langkah-langkah SADARI sebanyak 46,81\% responden, apabila langkah-langkah SADARI tidak dilakukan dengan lengkap dan benar maka di khawatirkan bagian payudara yang terdapat benjolan malah tidak teraba oleh WUS karena tidak lengkapnya melakukan langkah-langkah SADARI, maka dari itu perlunya dilakukan langkah-langkah SADARI dengan lengkap dan benar karena hal tersebut penting agar dapat dideteksi dengan lebih baik dan terakhir pertanyaan mengenai tahapan SADARI hanya sebanyak 50,00\% responden, apabila tahap awal dengan memperhatikan bentuk dan ukuran payudara tidak dilakukan maka WUS dikhawatirkan tidak dapat menyadari bagaimana bentuk normal payudaranya dan ada tidaknya perubahan dari waktu ke waktu.

Bila ditinjau dari umur, ada hubungan antara kelompok umur terhadap tingkat pengetahuan tentang deteksi dini kanker payudara. Responden yang memiliki umur 20-30 tahun sebanyak 18,00\% cenderung memiliki pengetahuan dalam kategori baik lebih banyak, sementara responden yang memiliki umur $>30$ tahun cenderung 
memiliki pengetahuan kurang. Hasil ini maka pengalaman dan pengetahuan juga sangat berbeda dengan landasan teori yang semakin bertambah. menyatakan semakin tinggi usia seseorang

Tabel 3. Pengaruh karakteristik responden terhadap tingkat pengetahuan

\begin{tabular}{|c|c|c|c|c|}
\hline \multirow[b]{2}{*}{ Karakteristik } & \multicolumn{4}{|c|}{ Pengetahuan } \\
\hline & $\begin{array}{c}\text { Kurang } \\
\text { n (\%) }\end{array}$ & $\begin{array}{c}\text { Cukup } \\
\text { n (\%) }\end{array}$ & $\begin{array}{l}\text { Baik } \\
\text { n (\%) }\end{array}$ & Nilai $p$ \\
\hline \multicolumn{5}{|l|}{ Umur Responden } \\
\hline 20-30 tahun & $8(16,00 \%)$ & $33(66,00 \%)$ & $9(18,00 \%)$ & 0,000 \\
\hline$>30$ tahun & $27(61,36 \%)$ & $12(27,27 \%)$ & $5(11,36 \%)$ & \\
\hline \multicolumn{5}{|l|}{ Pendidikan } \\
\hline SMP & $11(43,31 \%)$ & $12(46,15 \%)$ & $3(11,54 \%)$ & 0,212 \\
\hline SMA & $21(46,67 \%)$ & $18(40,00 \%)$ & $6(13,33 \%)$ & \\
\hline D3/S1 & $3(15,00 \%)$ & $13(65,00 \%)$ & $4(20,00 \%)$ & \\
\hline S2 & $0(0,00 \%)$ & $2(66,67 \%)$ & $1(33,33) \%$ & \\
\hline
\end{tabular}

\section{Status Pekerjaan}

\begin{tabular}{|c|c|c|c|c|}
\hline Buruh & $9(69,23 \%)$ & $4(30,77 \%)$ & $0(0,00 \%)$ & 0,007 \\
\hline PNS/Pegawai & $9(25,71 \%)$ & $19(54,29 \%)$ & $7(20,00 \%)$ & \\
\hline Wiraswasta & $4(16,67 \%)$ & $14(58,33 \%)$ & $6(25,00 \%)$ & \\
\hline IRT & $11(68,75 \%)$ & $5(31,25 \%)$ & $0(0,00 \%)$ & \\
\hline Pelajar & $2(33,33 \%)$ & $3(50,00 \%)$ & $1(16,67 \%)$ & \\
\hline
\end{tabular}

Hal tersebut bisa terjadi karena pengetahuan. kemajuan teknologi dan informasi yang tidak terbatas dan bisa diakses oleh setiap orang sehingga tidak jarang orang yang lebih muda cenderung lebih pandai dan lebih sering berhubungan dan mengakses teknologi dan informasi seperti internet sehingga cenderung memiliki tingkat pengetahuan yang lebih tinggi.

Sedangkan bila ditinjau dari segi tingkat pendidikan, tidak ada hubungan
Bila ditinjau dari segi pekerjaan, ada hubungan antara pekerjaan terhadap tingkat pengetahuan, responden yang bekerja sebagai wirasawata sebanyak 25,00\% memiliki pengetahuan baik, PNS/Pegawai sebanyak 20,00\% memiliki pengetahuan baik, sementara responden yang tidak bekerja/IRT tidak ada yang memiliki pengetahuan baik tentang deteksi dini kanker payudara metode SADARI. Hal ini 
kemungkinan disebabkan kurangnya akses terhadap informasi baru khususnya tentang deteksi dini kanker payudara metode SADARI. Responden yang bekerja memiliki persentase pengetahuan baik lebih tinggi dari yang tidak bekerja kemungkinan hal ini Sikap Terhadap Deteksi Dini Kanker Payudara Metode SADARI

Tabel 4. Sikap terhadap deteksi dini kanker payudara metode SADARI

$$
\text { Sikap }
$$

\section{Frekuensi}

$(\mathrm{n}=94)$

50

44

94

Jumlah

Berdasarkan hasil penelitian yang telah dilakukan diperoleh sikap responden terhadap deteksi dini kanker payudara metode SADARI sebagian besar kurang sebanyak 53,19\% responden.

Dari sepuluh komponen pertanyaan sikap yang diajukan kepada responden, sebagian besar responden menjawab setuju karena perasaan takut terhadap hasil pemeriksaan responden menunda untuk melakukan deteksi dini SADARI dan juga responden lebih banyak setuju apabila disebabkan karena responden yang bekerja lebih banyak melakukan interaksi tersebut bisa lebih banyak diperoleh informasi tentang deteksi dini kanker payudara metode SADARI.

(\%)

Persentase

53,19

46,81
SADARI hanya dilakukan pada wanita yang sudah menikah saja. Mungkin hal ini yang menyebabkan sikap WUS lebih banyak pada ketegori kurang dimana WUS merasa ketakutan akan hasil pemeriksaan dan WUS menganggap SADARI hanya dilakukan pada wanita yang sudah menikah saja maka sikap ini yang membuat kurangnya WUS dalam melakukan deteksi dini SADARI. 
Tabel 5. Pengaruh karakteristik responden terhadap tingkat sikap

\begin{tabular}{lccc}
\hline \multirow{2}{*}{ Karakteristik } & \multicolumn{3}{c}{ Sikap } \\
\cline { 2 - 4 } & $\begin{array}{c}\text { Kurang } \\
\text { n (\%) }\end{array}$ & $\begin{array}{c}\text { Baik } \\
\text { n (\%) }\end{array}$ & Nilai p \\
\hline Umur Responden & $24(48,00 \%)$ & $26(52,00 \%)$ & 0,282 \\
20-30 tahun & $26(59,09 \%)$ & $18(40,91 \%)$ & \\
$>30$ tahun & & & \\
& & & \\
Pendidikan & & & \\
SMP & $19(73,08 \%)$ & $7(26,92 \%)$ & \\
SMA & $25(55,56 \%)$ & $20(44,44 \%)$ & \\
D3/S1 & $5(25,00 \%)$ & $15(75,00 \%)$ & \\
S2 & $1(33,33 \%)$ & $2(66,67 \%)$ & \\
Status Pekerjaan & & & \\
Buruh & & $6(46,15 \%)$ & \\
PNS/Pegawai & $7(53,85 \%)$ & $17(48,57 \%)$ & \\
Wiraswasta & $18(51,43 \%)$ & $11(45,83 \%)$ & \\
IRT & $13(54,17 \%)$ & $7(43,75 \%)$ & \\
Pelajar & $9(56,25 \%)$ & $3(50,00 \%)$ & \\
\hline
\end{tabular}

Tabel 6. Hubungan pengetahuan dan sikap responden terhadap SADARI

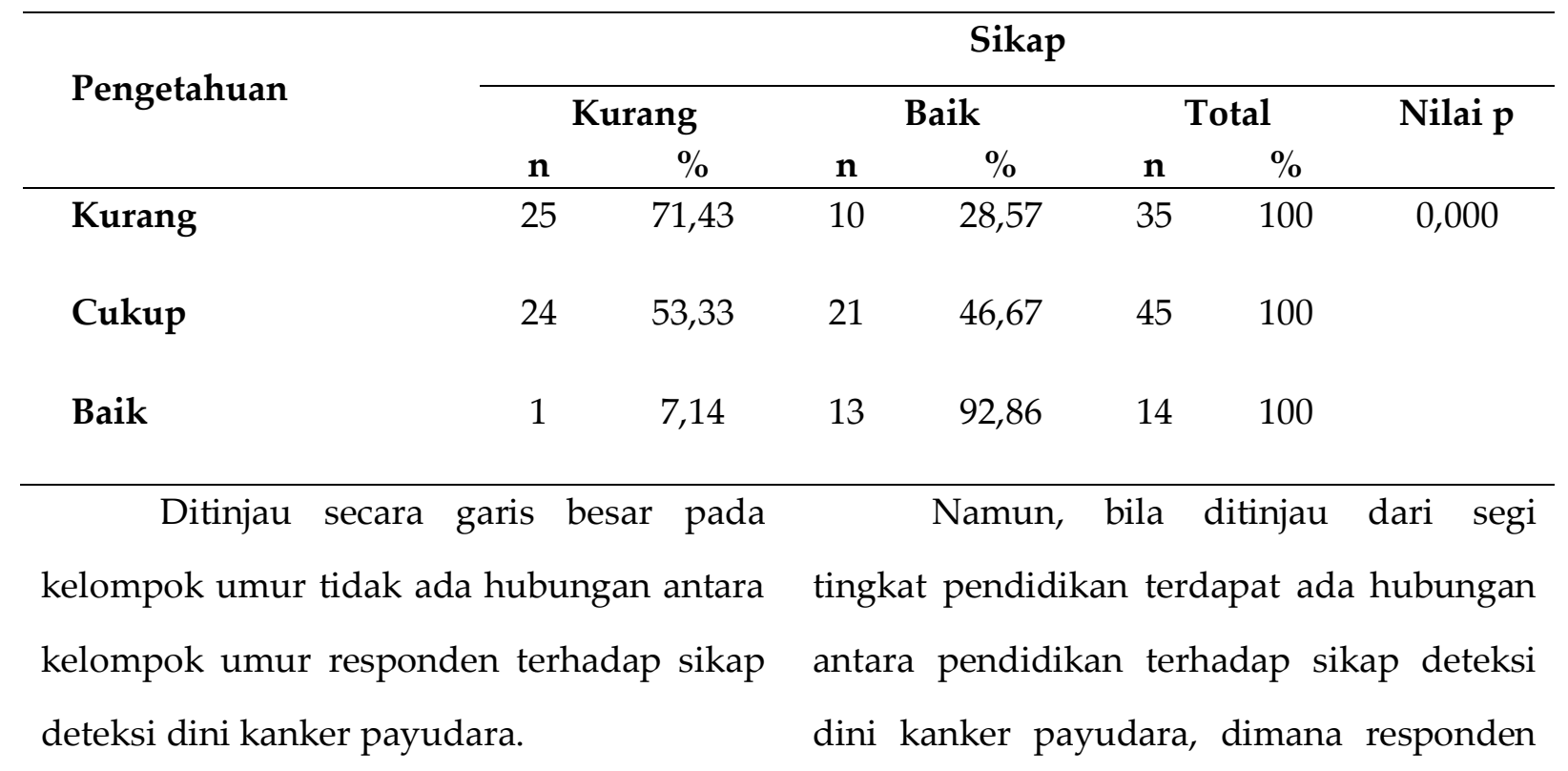


dengan pendidikan SMP sebanyak 73,08\% dan SMA sebanyak 55,56\% sebagian besar bersikap kurang, sementara responden dengan tingkat pendidikan yang lebih tinggi yaitu D3/S1 dan S2 mayoritas bersikap baik. Responden yang memiliki jenjang pendidikan lebih tinggi cenderung mempunyai pengetahuan yang lebih baik dan pada akhirnya mebentuk sikap yang baik/positif yang menurut mereka bermanfaat khususnya mengenai deteksi dini kanker payudara metode SADARI.

Bila ditinjau dari segi pekerjaan dalam penelitian ini tidak ada hubungan antara pekerjaan terhadap sikap deteksi dini kanker payudara. Menurut Teori yang dinyatakan oleh Notoadmodjo (2010), pengetahuan memegang peranan penting dalam pembentukan sikap. Dari hasil analisis dengan menggunakan uji Chi Square menunjukan adanya hubungan yang signifikan antara pengetahuan terhadap sikap deteksi dini SADARI pada WUS yang ditujukan dengan hasil nilai p-value yang didapatkan $<0,05$. Pada hasil penelitian ini diperoleh WUS yang memiliki tingkat pengetahuan kurang cenderung lebih banyak $(71,43 \%)$ bersikap kurang terhadap deteksi dini SADARI. Sedangkan WUS yang memiliki tingkat pengetahuan baik sebagian besar $(92,86 \%)$ bersikap baik terhadap deteksi dini SADARI. Hal ini sejalan dengan penelitian yang dilakukan oleh Widyasih ddk (2014) yang menunjukan bahwa variabel yang mempunyai pengaruh terhadap sikap wanita dalam deteksi dini SADARI di Dusun Gatak Gunung Kidul adalah tingkat pengetahuan dengan nilai pvalue $0,0172<0,05$. Hasil penelitian sesuai dengan teori Notoadmodjo (2010) yaitu dengan pengetahuan maka seorang individu menjadi tahu dan akan mempengaruhi pembentukan sikapnya.

\section{Perilaku Terhadap Deteksi Dini Kanker} Payudara Metode SADARI

Perilaku SADARI merupakan bagian dari perilaku kesehatan. Perilaku kesehatan adalah semua aktivitas atau kegiatan seseorang baik yang dapat diamati maupun yang tidak dapat diamati yang berkaitan

$$
\text { dengan pemeliharaan dan }
$$
peningkatan kesehatan (Notoatmodjo, 2010). Dengan adanya perilaku kesehatan yang baik berupa pelaksanaan SADARI secara rutin dan dengan langkah-langkah yang benar, maka akan membantu menentukan langkah apa yang akan dilakukan jika terjadi keadaan abnormal pada payudara. 
Tabel 7. Perilaku Terhadap Deteksi Dini Kanker Payudara Metode SADARI

\begin{tabular}{cccc}
\hline Perilaku & & $\begin{array}{c}\text { Frekuensi } \\
(\mathbf{n = 9 4 )}\end{array}$ & $\begin{array}{c}\text { Persentase } \\
\text { (\%) }\end{array}$ \\
\hline Tidak Melakukan & 60 & 63,83 \\
Melakukan & & 34 & 37,17 \\
\hline Jumlah & & $\mathbf{9 4}$ & $\mathbf{1 0 0}$ \\
\hline Berdasarkan hasil penelitian & yang & kanker payudara metode SADARI sebanyak \\
telah dilakukan diperoleh perilaku & WUS & 63,83\% responden.
\end{tabular}

sebagian besar tidak melakukan deteksi dini

Tabel 8. Pengaruh karakteristik responden terhadap perilaku SADARI

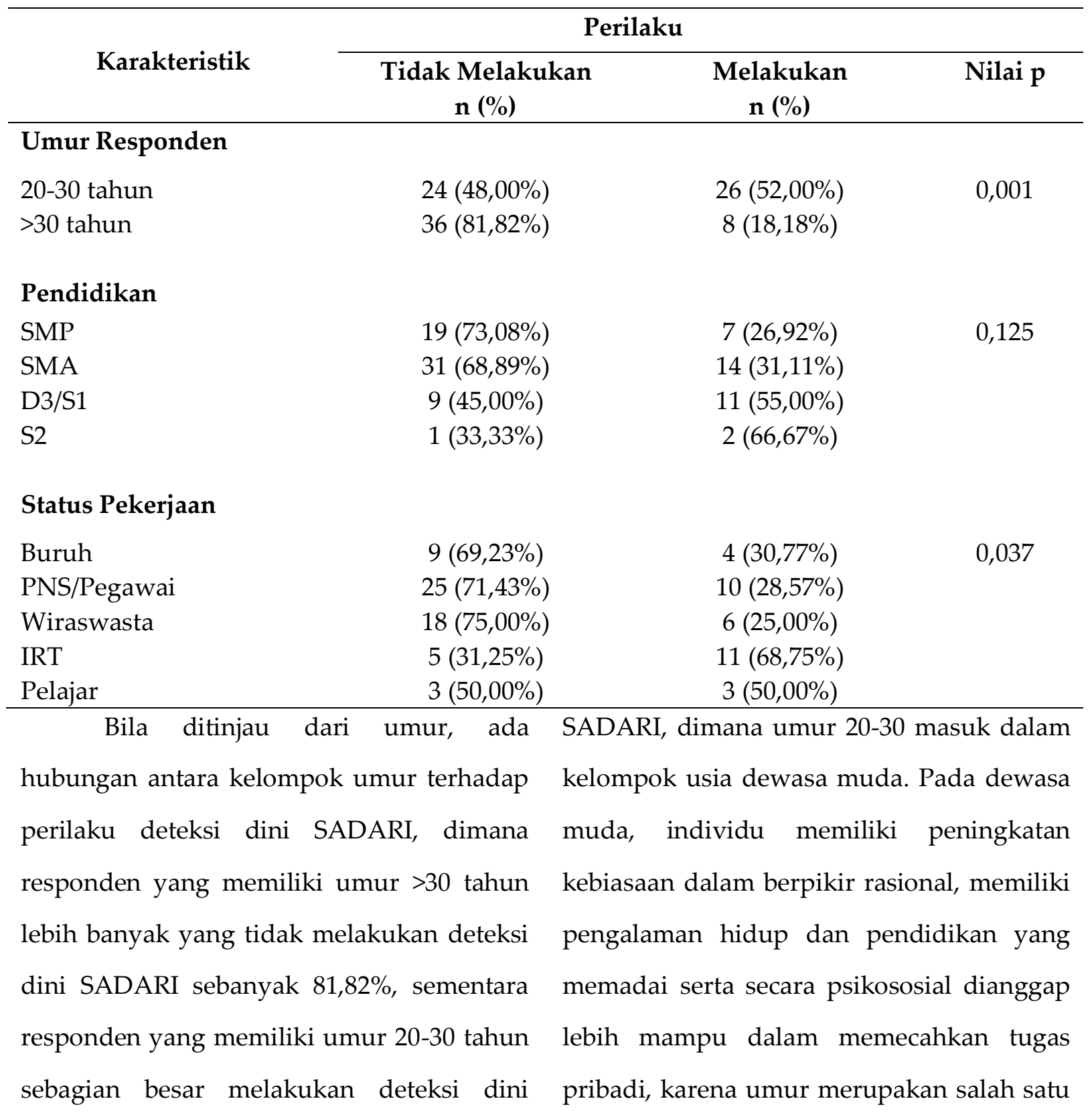


sifat karakteristik tentang orang yang sangat utama. (Potter dan Perry, 2005). Umur wanita dewasa muda umumnya lebih menjaga fisik mereka, sehingga untuk mendukung hal tersebut maka mereka mencari informasi dan memiliki pengetahuan yang lebih baik. (otto, 2003).

Bila ditinjau dari masing-masing tingkat pendidikan, tidak ada hubungan antara pendidikan terhadap perilaku deteksi dini kanker payudara. Sedangkan ditinjau dari segi pekerjaan ada hubungan antara pekerjaan terhadap perilaku deteksi dini kanker payudara, responden yang bekerja lebih banyak tidak melakukan deteksi dini SADARI, sementara responden yang tidak bekerja lebih banyak yang melakukan deteksi dini SADARI. Berdasarkan hasil wawancara mengapa WUS yang bekerja tidak melakukan deteksi dini kanker berlangsung lama.

payudara metode SADARI mereka mengatakan tidak memiliki waktu luang untuk melakukannya karena keseharian mereka sudah disibukan dengan pekerjaan. Karena terlalu sibuknya WUS dalam mengurus pekerjaannya WUS jadi lebih tidak peduli dengan dirinya sendiri.

Adanya kesadaran WUS serta pengaruh dari lingkungan sekitar juga dapat mengubah perilaku WUS terhadap SADARI. Namun perubahan perilaku tidak selalu melewati tahap-tahap di atas. Apabila penerimaan perilaku baru atau adopsi perilaku melalui proses seperti ini didasari oleh pengetahuan, kesadaran dan sikap yang positif, maka perilaku tersebut akan bersifat langgeng. Sebaliknya apabila perilaku itu tidak didasari oleh pengetahuan dan kesadaran, maka tidak akan Tabel 9. Hubungan sikap dan perilaku responden terhadap SADARI

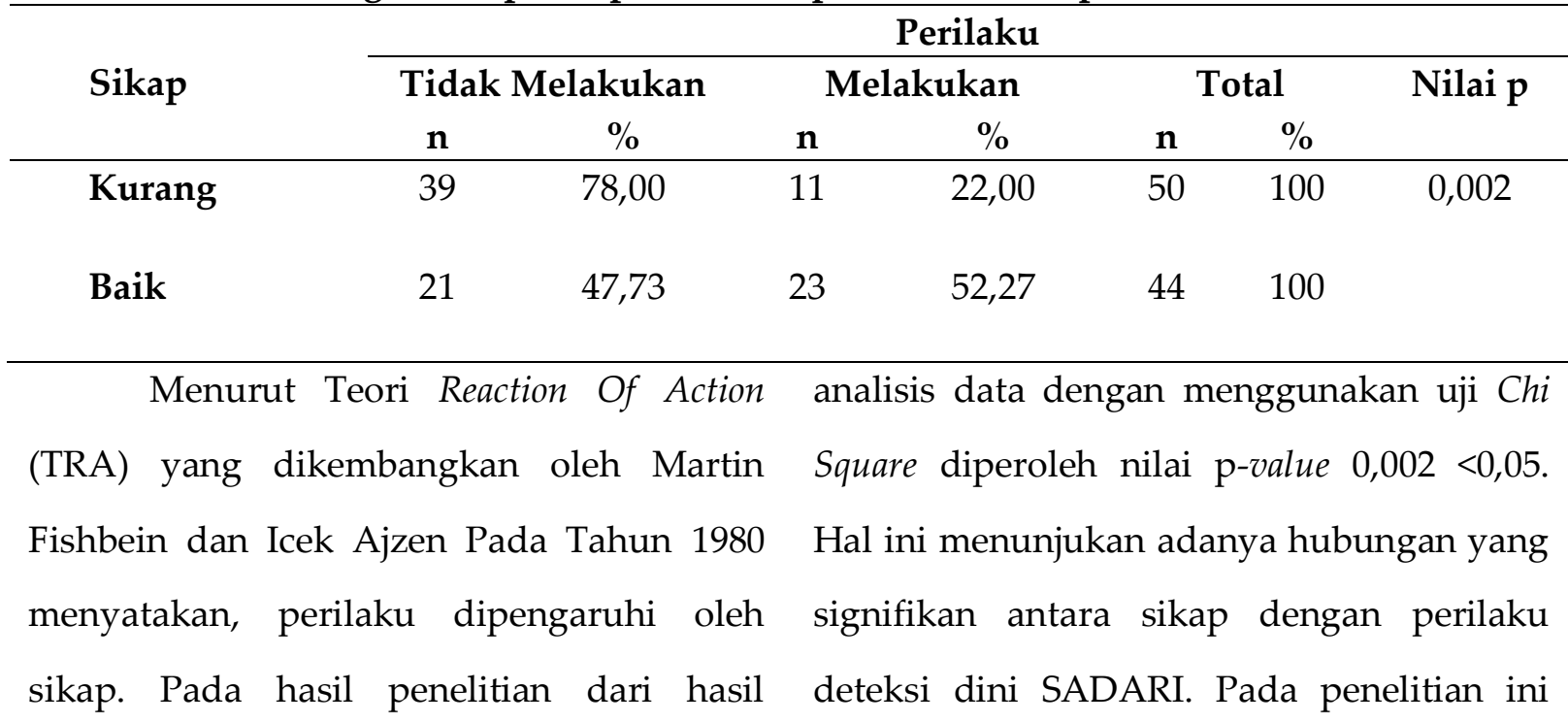


responden yang memiliki sikap baik sehingga menyebabkan sebagian besar WUS cenderung lebih banyak melakukan deteksi tidak melakukan deteksi dini kanker dini SADARI, sementara responden yang payudara dengan metode SADARI.

memiliki sikap kurang cenderung lebih banyak tidak melakukan deteksi dini SADARI.

Hasil penelitian ini diperkuat oleh penelitian yang dilakukan Maryanto dkk (2011), yang juga menemukan hubungan yang signifikan antara sikap WUS terhadap deteksi dini SADARI. Hal ini terlihat dari nilai p-value $0,0001<0,05$. Hasil penelitian ini sesuai dengan teori yang dinyatakan oleh Notoadmodjo (2014) yang menyatakan seseorang yang bereaksi atau memiliki sikap yang baik maka cenderung berperilaku baik pula, begitu juga sebaliknya jika memiliki sikap tidak baik akan berperilaku tidak baik pula. Hal ini menunjukan semakin baik sikap terhadap deteksi dini maka akan melakukan deteksi dini dalam mencegah kanker payudara.

\section{SIMPULAN}

Sebagian besar responden memiliki pengetahuan hanya pada kategori cukup dan sikap WUS yang kurang terhadap deteksi dini kanker payudara metode SADARI. Adanya kencenderungan tingkat pengetahuan yang rendah yang hanya sebagian besar pada kategori cukup menyebabkan sikap yang kurang pula,

\section{DAFTAR PUSTAKA}

Basri, A. H. (2011). Hubungan Pengetahuan, Sikap, dan Motivasi Terhadap Tindakan Pemeriksaan Payudara Sendiri Pada Mahasiswi FKM UNHAS. Universitas Kesehatan Masyarakat, Makassar.

Departemen Kesehatan Republik Indonesia. (2009). Profil Kesehatan Republik Indonesia. Departemen Kesehatan Republik Indonesia Bidang Pemberantasan Penyakit Tidak Menular.

Departemen Kesehatan Republik Indonesia. (2015). Profil Kesehatan Republik Indonesia. Departemen Kesehatan Republik Indonesia Bidang Pemberantasan Penyakit Tidak Menular.

Dinas Kesehatan Provinsi Bali. (2015). Laporan Tahunan Surveilans Terpadu Penyakit tahun 2015. Bali: Dinkes Provinsi Bali.

Dinas Kesehatan Kota Denpasar. (2015). Laporan Tahunan YKI cabang Kota Denpasar tahun 2015. Denpasar:

Dinkes Kota Denpasar 
Hawari, H. D. 2004, Kanker Payudara Dimensi

Psikoreligi, Fakultas Kedokteran Universitas Indonesia, Jakarta.

Kementrian Kesehatan Republik Indonesia. (2010). Laporan hasil riset kesehatan dasar (Riskesdas) Indonesia tahun 2010. Diakses pada tanggal 16 Januari 2017

Kementrian Kesehatan Republik Indonesia. (2015). Peraturan mentri kesehatan RI nomor 34 tahun 2015. Diakses pada tanggal 16 Januari 2017 dari http://peraturan.go.id/permen/keme nkes-nomor-34-tahun-2015.html

Ningrum, D. P. (2016). Faktor Yang Berhubungan Dengan Prilaku SADARI Pada Mahasiswa Fakultas Non Kesehatan Di Universitas Hasanuddin.

Nisman, W. A. (2011). Lima menit kenali payudara anda. Yogyakarta: CV. Andi Offset.

Notoatmodjo, S. 2003. Pendidikan dan Perilaku Kesehatan. Jakarta: PT. Rineka Cipta.

Notoatmodjo, S., 2005. Promosi Kesehatan Teori dan Aplikasi. Jakarta: Rineka Cipta.

Olfah, Y., Mendri, N. K., \& Badi'ah, A. (2013). Kanker Payudara \& SADARI. Yogyakarta: Nuha Medika.

OPotter, P.A., Perry, A.G. (2005). Buku ajar fundamental keperawatan : Konsep, proses, dan praktik. Edisi 4. Jakarta:

EGC

Purwanto, H. 2012. Pengantar Perilaku Manusia untuk Keperawatan. Jakarta :EGC.

Purwoastuti, E. (2008). Kanker Payudara (Pencegahan $\mathcal{E}$ Deteksi Dini). Yogyakarta: Kanisius.

Rasjidi I, 2009. Deteksi Dini dan Pencegahan Kanker Pada Wanita. Jakarta : Sagung Seto

World Health Organization (WHO). (2013). http://www.who.int/cancer/detection /breastcancer/en/index/html. Diakses pada 11 Februari 2017.

Yayasan Kanker Indonesia (YKI). (2012). YKI Jakarta Race. Diakses tanggal 16 Januari 2017 dari http://yayasankankerindonesia.org/2 012/yki-jakarta-race/ 